\title{
OBITUARY
}

\section{NINA ALEKSANDROVNA SHAKHOVA}

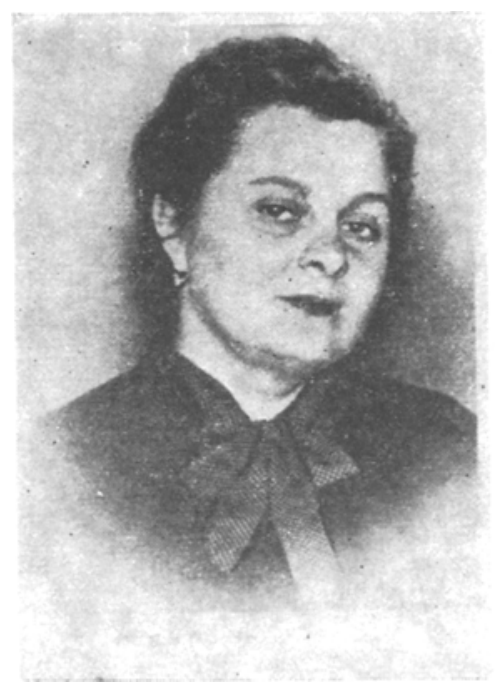

On March 18, 1976, Nina Aleksandrovna Shakhova, Doctor of Technical Sciences and professor of the Moscow Institute of Chemical Mechanical Engineering, passed away after a severe illness.

Shakhova was born in Moscow in 1920. After graduating from the Moscow Institute of Chemical Machine-Construction in 1944 she worked in the production division of the "Soyuzprommontazh" trust. In 1951 she entered graduate studies at the Moscow Institute of Chemical Machine-Construction, and from that time forward her life and activities were continuously connected with the Institute.

In 1954 she successfully defended her candidate's dissertation and continued her work in the "chemical production apparatus construction" faculty, first as an assistant, then as a lecturer. Her first studies of granulation of mineral fertilizers in a pseudoliquefied layer belong to this period. In particular, she was the first to demonstrate the possibility of producing simple and complex fertilizers in apparatus employing a pseudoliquefied layer, and she developed a method for producing complex mixed fertilizers in the form of multilayer granules. In 1966 Shakhova successfully defended her doctoral dissertation, and in 1967 was awarded the rank of professor.

In 1966 she became the head of the newly reorganized scientific research group on "granulation and drying in a pseudoliquefied layer." She created new directions in the field of granulation theory and developed a new jet model of the pseudoliquefied layer. Shakhova's work in the theory and practice of the pseudoliquefied layer was widely known in the Soviet Union and abroad.

But at no time did she remain enclosed within the walls of her laboratory. In particular, the first industrial granulator using a pseudoliquefied layer was put into operation under.her direct supervision.

In later years she devoted much of her energy to the task of education of highly qualified young specialists. Nina Aleksandrovna supervised 15 students preparing for the candidate's degree, and published over 200 scientific studies.

Together with her research work, she was deeply involved in scientific-organizational labors. She was the head of the chemical machine-construction Soviet and was a member of the Soviets of a number of related institutes.

Translated from Inzhenerno-Fizicheskii Zhurnal, Vol. 31, No. 3, pp. 554-555, September, 1976.

This material is protected by copyright registered in the name of Plenum Publishing Corporation, 227 West 17 th Street, New York, N.Y. 10011. No part of this publication may be reproduced, stored in a retrieval system, or transmitted, in any form or by any means, electronic, mechanical, photocopying, microfilming, recording or otherwise, without written permission of the publisher. A copy of this article is available from the publisher for $\$ 7.50$. 
For her service in the development of science and education Shakhova was awarded the Order of the Workers' Red Banner and several medals.

The bright memory of Nina Aleksandrovna Shakhova - a dedicated communist, sympathetic comrade, learned scholar, and attentive guide to the younger generation - will long remain in the hearts of all who knew and worked with her.

Editorial Board 